\title{
Rekürren Aftöz Stomatit Hastalarının Laboratuvar Bulguları
}

\author{
Laboratory Findings of Patients with Recurrent Aphthous Stomatitis
}

Bahar Sevimli Dikicier, Mahizer Yaldız, Büşra Aydın

Sakarya Üniversitesi Tip Fakültesi Eğitim ve Araştırma Hastanesi, Sakarya, Türkiye

ORCID

Bahar Sevimli Dikicier : https://orcid.org/0000-0002-1912-3846

Mahizer Yaldız : https://orcid.org/: 0000-0001-6981

Büşra Aydın : https://orcid.org/0000-0002-8832-8443

Yazışma Adresi / Correspondence:

Bahar Sevimli Dikicier

Sakarya Üniversitesi Tıp Fakültesi Eğitim ve Araştırma Hastanesi, Deri ve Zührevi Hastalıklar A. B. D. , Adapazarı, Sakarya T: :+90 $5326469196 \quad$ E-mail: bsevimlidikicier@gmail.com

Geliş Tarihi / Received : 26-06-2019 Kabul Tarihi / Accepted : 22-07-2019 Yayın Tarihi / Online Published: 29-08-2019

Dikicier B.S., Yaldız M., Aydın B., Rekürren Aftöz Stomatit Hastalarının Laboratuvar Bulguları, J Biotechnol and Strategic Health Res. 2019;3(2):96-99 DOİ:10.34084/bshr.582592

Öz

Amaç Rekürren aftöz stomatit (RAS), günümüzde etyolojisi halen aydınlatılamamış hastalıklar arasındadır ve çoğunlukla sağlıklı kişilerde ortaya çıkar. Lokal ve sistemik koşullar ile genetik, immünolojik ve mikrobial faktörlerin patogenezde rol oynadığı düsünülmektedir.

Oral aftlar; Behçet hastalığı, Reiter sendromu, rekürren eritema multiforme, Çölyak hastalığı, inflamatuar barsak hastalıkları, kollajen doku hastalıkları, AIDS, periyodik ateş, farenjit ve servikal lenfadenopati (PFAPA) sendromu) gibi bazı sistemik hastalıklarla birlikte görülebilmektedir. Bu nedenle RAS tanısı konulurken oral ülserasyonlarla seyreden hastalıkların ayırıcı tanısı yapılmalıdır.

Öykü ve fizik muayene sonrası, tam kan sayımı, vitamin B12, demir, folik asit yetersizliğinin değerlendirilmesi için testler istenmeli, replasman gereken durumlar saptanmalıdir.

Gereç ve Dermatoloji polikliniğimize başvuran, RAS ayırıcı tanısı yapılıp buna neden olan herhangi bir sistemik hastalık tanısı almayan hastaların tam kan sayımı, eritrosit Yöntemler sedimentasyon hızı(ESH), C-reaktif protein (CRP), serum demiri (SD), demir bağlama kapasitesi (DBK), B12 vitamini, folik asit, vitamin D ve HBsAg, anti HCV, anti HIV tetkiklerinin sonuçları hastaların dosya kayıtlarındanelde edilerek, cinsiyetlere göre karșlaștırmalı olarak değerlendirildi.

Bulgular Kırk bes hastanın laboratuvar bulgularının incelendiği calısmada hastaların yas ortalaması 33,9 (11-66) idi. Hastaların 23’ü kadın, 22’si erkeklerden olușmaktaydı. Cinsiyetler arasında yaş ortalamaları benzerdi, kadınlarda 36, erkeklerde 30. Hemoglobin düzeyleri kadınlarda erkeklere göre anlamlı olarak düşüktü ( $\mathrm{p=}=000$ ). Serum demiri ve demir bağlama kapasitesi ölçümleri de kadınlarda erkeklere göre anlamlı düzeyde düşük bulundu ( $\mathrm{p}=, 000)$. B12 vitamini, folik asit,, vitamin D düzeyleri ve CRP düzeyleri kadınlar ve erkekler arasında benzer düzeylerde ve $\mathrm{D}$ vitamini düzeyi dıșında referans aralıklar içindeydi.

Sonuç RAS tanısı koyulan hastalarda, D vitamini düzeyleri cinsiyet fark etmeksizin tümünde referans değerin altında saptanmıștır. Daha geniş çaplı kontrollü çalıșmalarla D vitamini düzeyinin etyopatogenezdeki rolünün incelemeye değer olduğunu düșünmekteyiz.

Anahtar Oral aft, rekürren aftöz stomatit, D vitamini yetersizliği, anem

Kelimeler

Abstract

Objective Recurrent aphthous stomatitis (RAS) is one of the aetiology of unexplained disease and occurs mostly in healthy individuals. Differential diagnosis of Behçet's disease, Reiter's syndrome, recurrent erythema multiforme, celiac disease, inflammatory bowel diseases, collagen tissue diseases, AIDS, periodic fever, pharyngitis and adenitis (PFAPA syndrome) should be made. After history and physical examination, complete blood count, B12, iron, folic acid and vitamin D deficiency should be evaluated and cases requiring replacement should be determined. The aim of this study was to evaluate hematological changes in patients with RAS.

Materials and Blood count, sedimentation, C-reactive protein, serum iron, iron binding capacity, vitamin B12, folic acid, 25 hydroxy vitamin D and HBsAg, anti HCV and anti HIV tests were evaluated

Methods from records and evaluated comparatively according to gender.

Results The mean age of the patients was 33.9 (11-66) years. 23 of the patients were female and 22 were male. Mean age of the genders was similar, 36 in women and 30 in men. Hemoglobin levels were significantly lower in women than in men $(p=000)$. Serum iron and iron binding capacity measurements were significantly lower in women $(p=000)$. Vitamin B12, folic acid, vitamin D levels and CRP levels were similar between women and men and were within the reference ranges except vitamin D levels. HBsAg, anti HCV and anti HIV positivity were not found.

Conclusion Vitamin D levels were found to be below the reference value in all patients regardless of gender. These findings suggest that the role of these findings in etiopathogenesis should be examined with larger controlled studies.

Keywords Oral aphtae, recurrent aphthous stomatitis, vitamin D deficiency, anemia 


\section{GIIRIŞ}

Rekürren aftöz stomatit (RAS), etyolojisi aydınlatılamamış hastalıklar arasındadır ve çoğunlukla sağlıklı kişilerde ortaya çıkar. RAS tanısı koyulurken oral aftlarla seyreden Behçet hastalığı, Reiter sendromu, rekürren eritema multiforme, Çölyak hastalığı, inflamatuar barsak hastalıkları, kollajen doku hastalıkları, AIDS, periyodik ateş- farenjit-servikal lenfadenopati(PFAPA sendromu) gibi hastalıkların ayırıcı tanısı yapılmalıdır. Öykü ve fizik muayene sonrası, tam kan sayımı, vitamin B12, serum demiri, folik asit ve vitamin $\mathrm{D}$ düzeyleri ölçülmeli ve giderilmesi gereken durumlar saptanmalıdır ${ }^{1}$. Bu çalışmada amacımız RAS'lı hastalarda laboratuvar bulgularını değerlendirmektir.

\section{MATERYAL ve METOD}

Ekim 2018-aralık 2018 arası 3 aylık dönemde dermatoloji polikliniğimize başvuran, RAS ayırıcı tanısı yapılıp buna neden olan herhangi bir sistemik hastalık tanısı almayan hastaların kan sayımı, eritrosit sedimantasyon hızı (ESH), C-reaktif protein (CRP), serum demiri (SD), demir bağlama kapasitesi (DBK), vitamin B12, folik asit, 25 hidroksi-vitamin D ve HBsAg, anti HCV, anti HIV tetkiklerinin sonuçları hasta dosya kayıtları incelenerek cinsiyetlere göre karşılaştırmalı olarak değerlendirildi.

\section{BULGULAR}

Kırk beş hastanın laboratuvar bulgularının incelendiği çalışmada hastaların yaş ortalaması 33,9 (11-66) idi. Hastaların 23'ü kadın, 22'si erkeklerden oluşmaktaydı. Cinsiyetler arasında yaş ortalamaları benzerdi, kadınlarda 36, erkeklerde 30. Hemoglobin düzeyleri kadınlarda erkeklere göre anlamlı olarak düşüktü $(\mathrm{p}=, 000)$. Serum demiri ve demir bağlama kapasitesi ölçümleri kadınlarda anlamlı olarak düşük bulundu ( $\mathrm{p}=, 000)$. B12 vitamini, folik asit, vitamin D düzeyleri ve CRP düzeyleri kadınlar ve erkekler arasında benzer düzeylerde ve $\mathrm{D}$ vitamini düzeyi dışında referans aralıklar içindeydi. HBsAg, anti HCV, anti HIV pozitifliğine rastlanmadı ( Tablo1 ve 2).
Tablo 1. RAS hastalarının cinsiyete göre laboratuvar bulgularının dağılımı.

\begin{tabular}{|l|c|c|}
\hline Anemi $(\mathrm{K}:<12 \mathrm{mg} / \mathrm{dl}, \mathrm{E}:<13 \mathrm{mg} / \mathrm{dl})$ & $7(\% 30,4)$ & $4(\% 18,1)$ \\
\hline Ferritin yetersizliği $(<20 \mathrm{Mg} / \mathrm{L})$ & $12(\% 52,1)$ & $3(\% 13,6)$ \\
\hline Vit B12 yetersizliği $(<187 \mathrm{ng} / \mathrm{L})$ & $1(\% 4,3)$ & $3(\% 13,6)$ \\
\hline Vit D yetersizliği $(<30 \mathrm{ng} / \mathrm{mL})$ & $21(\% 91,3)$ & $18(\% 81,8)$ \\
\hline
\end{tabular}

Tablo 2. RAS hastalarında saptanan laboratuvar bulgularının özeti.

\begin{tabular}{|l|c|c|}
\hline & $\mathrm{K}(\mathrm{n}=23)$ & $\mathrm{E}(\mathrm{n}=22)$ \\
\hline $\begin{array}{l}\text { Hematolojik ve nutrisyonel } \\
\text { bozukluklar } \\
\text { (Anemi, demir eksikliği, vit B12 } \\
\text { eksikliği) }\end{array}$ & $19(\% 82,6)$ & $8(\% 36,3$ \\
\hline Vit D yetersizliği & $21(\% 91,3)$ & $18(\% 81,8)$ \\
\hline
\end{tabular}

\section{TARTIŞMA}

RAS, etrafı eritemli keskin sınırlı halo ile çevrili merkezinde sarımsı-gri psödomembran olan ağrılı, yuvarlak, yüzeysel ülserlerdir. Oral mukozanın en sık görülen ülseratif hastalığıdır ${ }^{2}$.

Aft terimi, "ateşe vermek" veya "alevlenmek" anlamına gelen Yunanca aphthi kelimesinden türetilmiştir ve ilk kez Hipokrat tarafından, ağızda sık görülen bu durumla ile ilişkili ağrıyı tanımlamak için kullanıldığı düşünülmektedir. Belirgin özelliklerine rağmen, tüm RAS formları yaşam kalitesi üzerinde önemli bir etkiye sahiptir ${ }^{3}$.

Genel popülasyonun yaklaşı \% 20'si RAS'tan etkilenmektedir, ancak çalışılan etnik ve sosyoekonomik gruplara bağlı olarak görülme sıklığı \% 5 ila\% 50 arasında değişmektedir ${ }^{4,5,6}$.

Eğer RAS, üçüncü on yıldan sonra ve yetişkin yaşamında şiddetli bir şekilde başlarsa veya ciddi şekilde artarsa, durumun etiyolojisinin hematolojik, immünolojik, bağ dokusu hastalı̆̆ veya Behçet sendromu gibi altta yatan bir tıbbi hastalığa bağlı olabileceği şüphesini dişlamak gerekir. RAS hastaları genellikle ülser ortaya çıkmadan 2 ila 48 saat kadar süren prodromal yanma hissi yaşarlar. RAS ülserleri genellikle keratinize olmayan oral mukozada gelişir, buk- 
kal ve labiyal mukoza en yaygın bölgelerdir ve skar bırakmadan yaklaşık 10 ila 14 gün sürede iyileşir ${ }^{7}$.

Klinik görünümüne göre üç RAS formu vardır: Minor (vakaların $>\% 70$ i), major (\% 10) ve herpetiform (\% 10). Bu alt tipler morfoloji, dağılım, şiddet ve prognoz açısından farklılık gösterir. Minor tip ülserler $1 \mathrm{~cm}$ 'den küçük olup skar bırakmadan iyileşmelerine rağmen, major ülserler 1 cm’den büyüktür ve skar bırakarak iyileşirir ${ }^{8,9}$.

RAS etiyolojisinde genetik, immünolojik faktörler, nutrisyonel veya hematolojik eksiklikler, hormonal faktörler ve travma, stres, ilaçlar, mikroorganizmalar gibi bazı çevresel nedenler suçlanmaktadır ancak bu faktörlerin dişlanması ya da düzeltilmesine rağmen RAS olgularının bir kısmında etiyoloji kesin olarak belirlenememektetir ${ }^{1}$.

Yapılan araştırmalarda RAS hastalarının \%10-20 kadarında demir, folik asit, B12 vitamini eksiklikleri gösterilmiştir. Pişkin ve ark. tarafından RAS hastalarında serum demir, ferritin, folik asit ve B12 vitamin değerlerine bakılmış; vitamin B12 düzeyi kontrol gruba göre anlamlı oranda düşük bulunurken, diğer parametrelerde farklılık gözlenmemiştir ${ }^{11}$. Porter ve ark.'nın yaptıkları bir çalışmada; ferritin, B12 vitamini, folik asit düzeyleri RAS hastalarında kontrol grubuna göre düşük bulunmasına rağmen, yalnızca ferritin düzeyindeki düşüklük istatistiksel olarak anlamlı bulunmuştur ${ }^{11}$.

Bizim çalışmamızda 6 kadın hastada anemi saptanırken 1'i erkek 15 hastada ferritin düzeyleri düşük saptandı. Demir eksikliği olan hastalarda hücresel immünite defektleri ve oral mukoza değişiklikleri tanımlanmıştır ${ }^{10}$.

Hastalarımızın \%86’sında vitamin D düzeyi düşük ölçüldü. 4 erkek 2 kadın hasta dışında tüm hastaların vitamin $\mathrm{D}$ düzeyleri referans değerin altında idi. $25 \mathrm{OH}$ vitamin $\mathrm{D}$ seviyesinin RAS hastalarında kontrol grubuna göre düşük bildiren çalışmaların yanında bir çalışmada fark olmadığı da bildirilmiştir ${ }^{11-13}$. D vitamini yetersizliğinin RAS olgula- rında neden mi, sonuç mu olduğu henüz tartışılmaktadır. $\mathrm{D}$ vitamini reseptörü, antijen sunan hücreler (ASH) dahil olmak üzere bağışıklık sistemi hücre tiplerinin çoğunda bulunmuştur. D vitamini antijen sunumunu, T hücrelerinin çoğalmasını ve B hücreleri tarafından antikor üretimini baskılar. Salgılanan sitokinlerin profili D vitamini ile değiştirilir; Th1 kaynaklı sitokin üretimi azalır ve Th2 kaynaklı sitokin üretimi $\operatorname{artar}^{16-18}$.

Proinflamatuar Th1 tipi sitokinlerin artan üretimi ve antiinflamatuar Th2 tipi sitokinlerin ve TGF-B'nin azalmış üretimi, RAS’ta birçok yazar tarafından otoimmünizasyon için bir risk faktörü olarak tanımlanmıştır ${ }^{19-21}$.

Sonuç olarak; RAS tanısı ile olası yetersizliklere yönelik yapılan tetkiklerde bizim hastalarımızın büyük bir kısmında, D vitamini düzeyleri cinsiyet fark etmeksizin referans değerin altında saptanmıştır. Bu bulgular daha geniş çaplı kontrollü çalışmalarla bu D vitamini yetersizliğinin RAS etyopatogenezindeki rolünün incelenmeye değer olduğunu düşündürmektedir. 
Journal of BSHR 2019;3(2):96-99

DİKİCIER, YALDIZ, AYDIN, Rekürren Aftöz Stomatit Hastalarının Laboratuvar Bulguları

\section{Kaynaklar}

1. Zeynep Topkarcl. Zorlu Oral Hastaliklarda Güncel Tedavi: Rekürren Oral Aftozis Türkderm 2012; 46 Özel Sayt 2: 123-9).

2. Porter SR, Scully C, Pedersen A. Recurrent aphthous stomatitis. Crit Rev Oral Biol Med. 1998;9(3):306-321.

3. Compilato D1, Carroccio A, Calvino F, et al. Hematological deficiencies in patients with recurrent aphthosis. J Eur Acad Dermatol Venereol. 2010;24(6):667-673.

4. Epidemiologic aspects of recurrent aphthous ulcerations.Ship II Oral Surg Oral Med Oral Pathol. 1972 Mar; 33(3):400-6.

5. Recurrent aphthous stomatitis: clinical characteristics and associated systemic disorders. Rogers RS 3rdSemin Cutan Med Surg. 1997 Dec; 16(4):278-83.

6. Ship JA, Chavez EM, Doerr PA, Henson BS, Sarmadi M. Recurrent aphthous stomatitis. Quintessence Int. $2000 \mathrm{Feb}$; 31(2):95-112.

7. Woo SB, Greenberg MS. Ulcerative, vesicular and bullous lesions. In: Greenberg MS, Glick M, Ship JA, editors. Burket's Oral Medicine. 11. Hamilton, Canada: BC Decker; 2008. pp. $41-76$.

8. Crispian Scully CBE. The oral cavity and lips. In: Burns T, Breathnach S, Cox N, Griffiths C, eds. Rook's Textbook of Dermatology. 7th ed. Oxford: Blackwell Science Ltd; 2004. p.66.43.

9. Scully $C$, Gorsky $M$, Lozada-Nur F. The diagnosis and management of recurrent aphthous stomatitis: a consensus approach. J Am Dent Assoc 2003;134:200-7.

10. Nilgün Solak Tekin,Selim Aydemir,Tuna Sezer,Sibel Duysak, H. Cevdet Altınyazar. Rekürren Aftöz Stomatitli Hastalarda Hematolojik Değişiklikler. Turkiye Klinikleri J Dermatol. 2007;17(3):150-4

11. Öztekin A, Öztekin C. Vitamin D levels in patients with recurrent aphthous stomatitis. BMC Oral Health. 2018 Nov 9;18(1):186.
12. Khabbazi A, Ghorbanihaghjo A, Fanood F, et al. A comparative study of vitamin D serum levels in patients with recurrent aphthous stomatitis. Egypt Rheumatol. 2014;37:133-137.

13. Krawiecka E, Ślebioda Z, Szponar E, Kowalska A, Dorocka-Bobkowska B. Vitamin D status in recurrent aphthous stomatitis. Postepy Dermatol Alergol. 2017;34(6):612-617

14. Piskin S, Sayan C, Durukan N,Senol M. Serum iron, ferritin, folic acid, andvitamin B12 levels in recurrent aphthous stomatitis.J Eur Acad Dermatol Venereol.2002 Jan;16(1):66-7.

15. Porter SR, Scully C, Flint S. Hematologic status in recurrent aphthous stomatitis compared with other oral disease. Oral Surg Oral Med Oral Pathol 1988;66:41-44.

16. Myszka M, Klinger M. The immunomodulatory role of vitamin D. Postepy Hig Med Dosw 2014; 68: 865-78.

17. Adorini L, Penna G, Giarratana N, et al. Dendritic cells as targets for immunomodulation by vitamin D receptor ligands. J Steroid Biochem Mol Biol 2004; 89-90: 437-41.

18. Karagün E, Ergin C, Baysak S, et al. The role of serum vitamin D levels in vitiligo. Adv Dermatol Allergol 2016; 33: 300-2.

19. Bachtiar EW, Cornain S, Siregar B, Raharjo TW. Decreased CD4+/CD8+ ratio in major type of recurrent aphthous ulcers: comparing major to minor types of ulcers. Asian Pac J Allergy Immunol 1998; 16: 75-9.

20. Buno IJ, HuffC, Weston WL, et al. Elevated levels of interferon gamma, tumor necrosis factor alpha, interleukins 2, 4 and 5, but not interleukin 10, are present in recurrent aphthous stomatitis. Arch Dermatol 1998; 134: 827-31.

21. Häyrinen-Immonen R, Nordström D, Malmström M, et al. Immune-inflammatory cells in recurrent oral ulcers (ROU). Scand J Dent Res 1991; 99: 510-8. 